\title{
The use of nonglycosylated recombinant human bone morphogenic protein 2 (rhBMP-2) released from a fibrin matrix to promote arthrodesis in an equine pastern joint
}

Britta S. Lippold', Hugo G. Schmoeke12,4, Franz E. Weber ${ }^{3}$, Jason C. Schense ${ }^{4,5}$, Jeffrey A. Hubbell' ${ }^{4}$ Gottlieb Ueltschi' und Walter Brehm?

Equine Clinic ${ }^{1}$ and Small Animal Clinic ${ }^{2}$, Department of Clinical Veterinary Medicine, Vetsuisse Faculty University of Berne, Clinic for maxilla-fascial surgery, University of Zurich ${ }^{3}$, Inst. Biomedical Engineering ETH Zurich ${ }^{4}$ und KurosBiosurgery, Zurich ${ }^{5}$, Switzerland

\begin{abstract}
Summary
Arthrodesis is often necessary as the definitive treatment of degenerative joint disease. In the horse, the extended bone healing period presents particular challenges and requires long rest periods. In the last years bone growth factors were isolated, which then have been shown to accelerate bone healing after arthrodesis in dogs. This report documents the use of bone growth factors to accelerate bony fusion in a horse. Specifically, nonglycosylated rhBMP-2, was used in combination with arthrodesis in a 5-year-old Warmblood mare with severe degenerative joint disease in the left front pastern joint. Surgical technique included the stabilization of the arthrodesis with three $5.5 \mathrm{~mm}$ cortical screws inserted in lag fashion. The articular cartilage was partially removed without transsecting the collateral ligaments. Nonglycosylated rhBMP-2 was administered into sagittal defects created in the centrally located cartilage. Follow-up clinical examinations and radiographs revealed a successful outcome within 10 months after surgery with the horse reaching the intended athletic use. The nonglycosylated rhBMP-2/fibrin composite was easy to apply and well tolerated. The composite might be useful to promote joint fusion and fracture healing in combination with internal fixation in equines.
\end{abstract}

Keywords: arthrodesis, nonglycosylated rhBMP-2, bone healing, pastern joint, equine,

\section{Die Verwendung von nichtglykosyliertem rekombinantem humanem Bone Morphogenic Protein 2 (rhBMP-2), freigesetzt aus} einer Fibrinmatrix, zur Förderung der Arthrodese des Krongelenks bei einem Pferd

\begin{abstract}
Als definitive Behandlung einer chronischen Gelenkserkrankungen kommt häufig nur die Arthrodese in Frage. Die lange Abheilungsdauer des Knochens stellt beim Pferd besondere Herausforderungen und bedingt eine lange Ruhephase des Tieres. In den letzten Jahren konnten Knochenwachstumsfaktoren isoliert werden, deren Einsatz bei Hunden zu einer schnelleren knöchernen Verheilung von Arthrodesen führte. Dieser Fallbericht dokumentiert den Einsatz eines Knochenwachstumshormones zur Förderung der Knochenheilung bei einem Pferd. Ein solches Präparat, nichtglykosyliertes rhBMP-2 in einem Fibringel, wurde bei der Arthrodese einer 5 Jahre alten Selle-Français-Stute mit hochgradiger degenerativer Gelenkserkrankung des linken vorderen Krongelenks angewendet. Die Arthrodese erfolgte mit drei als Zugschrauben eingesetzten $5.5 \mathrm{~mm}$ Kortikalis-Schrauben. Dabei wurde der Gelenksknorpel partiell entfernt, ohne die Kollateralbänder zu durchtrennen. Die Applikation des nichtglykosylierten rhBMP-2 im Fibrinhydrogel erfolgte lokal in den zentralen Gelenkspalt. Die nachfolgenden klinischen und radiologischen Untersuchungen zeigten ein erfolgreiches Ergebnis innerhalb von 10 Monaten nach der Operation im Sinne einer knöchernen Verheilung sowie der beabsichtigten reiterlichen Nutzbarkeit des Pferdes. Das rhBMP-2/Fibrin-Composite ist während der Operation einfach anzuwenden und wurde gut toleriert. In Kombination mit einer internen Fixation könnte sich dieses Präparat zur Förderung der Gelenksfusion oder Frakturheilung bei Pferden als nützlich erweisen.
\end{abstract}

Schlüsselwörter: Arthrodese, nichtglykosyliertes rhBMP-2, Knochenheilung, Krongelenk, Pferd

\section{Introduction}

Arthrodesis of the proximal interphalangeal joint (PIPJ) has successfully been used for the treatment of advanced degenerative joint disease (DJD) (Martin et al. 1984, Steenhaut et al. 1985, Rick et al. 1986, Caron et al. 1990, MacLellan et al. 2001, Schaer et al. 2001), luxations (Steenhaut et al. 1985, MacLellan et al. 2001), subluxations (Martin et al. 1984, Steenhaut et al. 1985, Caron et al. 1990, Schaer et al. 2001), sepsis of the pastern joint (Groom et al. 2000) and fractures involving the pastern joint (Colahan et al. 1981, Martin et al. 1984, Steenhaut et al. 1985, Rick et al. 1986, Doran et al. 1987, Bukowiecki and Bramlage 1989, Caron et al. 1990, Crabill et al. 1995, MacLellan et al. 2001, Schaer et al. 2001). Various surgical techniques have been used, most of them refer to three principles as being important for the promotion of arthrodesis: removal of articular cartilage, internal fixation and external immobilisation (Stashak 2002).

Surgical fusion of the PIPJ provides the best option for lame horses due to chronic DJD. Generally the outcome for arthrodesis of the pastern joint in the pelvic limb is considered to be better than in the thoracic limb (Schneider et al. 1978, Martin et al. 1984, Caron et al. 1990, Schaer et al. 2001). Autogenous cancellous bone grafts are not routinely used for arthrodesis of the pastern joint. It is reported that bone grafts substantially reduce the time to osseous union following arthrodesis (Rick et al. 1986), but this benefit may be negated by the decrease in contact area between the subchondral 
bone plates (Watkins 1996). One alternative therapy could be the use of recombinant bone morphogenic proteins, the only differentiative factors able to singularly induce new bone formation in vivo (Kirker-Head 1995). To the authors' knowledge no case has been reported using nonglycosylated rhBMP-2 released from a fibrin matrix to promote bony fusion in equine surgery.

\section{Case report}

History

A five-and-a-half-year-old Selle Français mare was referred because of a left forelimb lameness. An acquired mild contractural deformity with development of a club-foot in the right forelimb and a selective weight bearing in the contralateral limb was noticed at 6 months of age. Conservative treatment in the right forelimb was successful, but for four years the horse was persistently lame in the left forelimb, only kept on pasture and remained unbroken. Physical examination indicated a diffuse enlargement of the pastern region of the left forelimb with a marked lameness (grade 3 out of 5) with exacerbation by left hand circling and trotting. The flexion test of the distal limb was positive and the lameness completely blocked out with a pastern ring block. Radiography revealed an advanced DJD of the pastern joint with narrowing of the

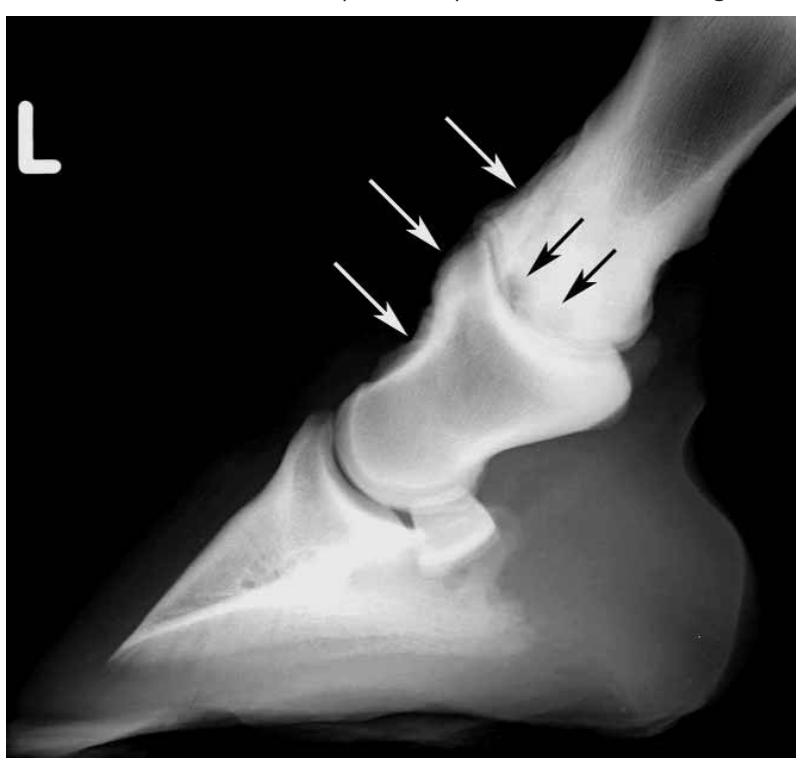

Fig 1 Radiograph taken one day before surgery showing the advanced DJD with periarticular bone proliferation (white arrows), subchondral lucencies at the distal P1 (black arrows) and narrowing of the joint space.

Das präoperative Röntgenbild zeigt die fortgeschrittene degenerative Gelenkserkrankung mit periartikulärer Knochenzubildung (weisse Pfeile), subchondralen Aufhellungszonen am distalen Fesselbein (schwarze Pfeile) sowie die Verengung des Gelenkspalts.

joint space, periarticular bone proliferation and subchondral lucencies in the subchondral bone at the distal end of the proximal phalanx (Fig. 1). The opposite pastern region did not show any sings of DJD radiographically.

\section{Drug therapy}

The mare weighed $536 \mathrm{~kg}$ at the time of the surgery. Perioperative antibiotic treatment consisted of Penicillin G (28.000 IU/kg bwt QID i.v.) and Gentamicin (7 mg/kg bwt
SID i.v.) for five days. Flunixine-meglumine $(1.1 \mathrm{mg} / \mathrm{kg}$ bwt/day) was administered i.v. on the first and second postoperative day. Nonsteroidal inflammatory treatment was continued per os with phenylbutazone for another fourteen days (three days $\lg$ BID, eleven days $\lg$ SID).

\section{Fibringels}

The components for the gels were prepared such that the final concentration obtained was $8 \mathrm{mg} / \mathrm{ml}$ fibrinogen, $2.5 \mathrm{mM}$ $\mathrm{Ca}++, 10 \mathrm{NIH}$ Units/ml of thrombin and $600 \mathrm{mg}$ nglyrhBMP-2/ml gel. Gelation began after mixing and injection of the components into the joint gap. Gelation time was approximately 60 seconds. The contamination of the components with small amounts of blood in the wound did not influence the gelation properties.

\section{Ngly-rhBMP-2}

Expression constructs for mature BMP-2 and -4 (GenBank: M22489; M22490) were generated and the proteins expressed and harvested as previously reported (Weber et al. 2002). The biologic activity of that nonglycosylated rhBMP-2 was assessed via assay of elevation of the alkaline phosphatase activity of osteoblastic cells in vitro and compared to that of the wild-type rhBMP-2 produced in $\mathrm{CHO}$ cells (ap nongly-

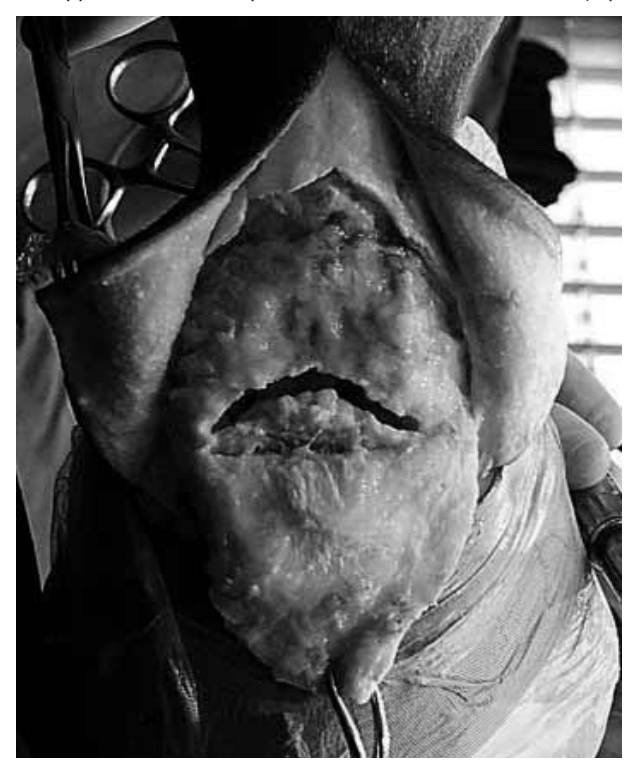

Fig 2 Intra-operative photograph, showing the dorsal aspect of the PIPJ with partially removed articular cartilage.

Die intraoperative Aufnahme zeigt den dorsalen Aspekt des Krongelenkes, bei dem der Gelenkknorpel teilweise entfernt wurde.

rhBMP-2 $=323 \pm 11 \mathrm{mU} / \mathrm{mg}$; ap wild-type rhBMP-2 $=360$ $\pm 14 \mathrm{mU} / \mathrm{mg}$ ) (Schmoekel et al. 2004a).

\section{Surgery}

Arthrodesis was performed using a modification of the technique described by Aver (2000). An inverted T-shaped skin incision was made over the dorsal aspect of the pastern to expose the long digital extensor tendon and the proximal interphalangeal joint. An inverted V-shaped incision was made in the common digital extensor tendon, which was reflected distally to expose the dorsal aspect of the PIPJ. An extensive periarticular fibrous and bony reaction was present. 
In contrast to previously described surgical techniques, neither transection of the medial and lateral collateral ligaments nor removal of periarticular proliferative bone was performed. Instead of completely opening the joint, only the dorsal joint capsule was dissected and the articular cartilage of the dorsal aspect of the joint removed (Fig. 2.). In addition three sagittal defects ( $1 \mathrm{~cm}$ wide) were created in the centrally located cartilage using a motorised burr. Three $5.5 \mathrm{~mm}$ cortical screws were then inserted in a semi parallel alignment in lag fashion. Intra-operative radiographs were taken to confirm appropriate implant placement. The operation field was flushed with physiological $\mathrm{NaCl}$-solution. Before tightening the screws to compress the joint surfaces the fibrin/ngly-rhBMP-2solution was injected into the prepared cartilage defects and gelation took approximately 60 seconds to form a hydrogel. With just a flap of the extensor tendon being left open at the level of the PIPJ, a final solution of fibrin/ngly-rhBMP-2 was injected (total $900 \mathrm{mg}$ ngly-rhBMP-2 in $1.5 \mathrm{ml}$ fibrin). The suture of the extensor tendon was completed and the skin closed with simple interrupted sutures. A standard lower limb cast was applied with the fetlock angle in a natural standing position and the horse hand-recovered in a padded recovery stall.

\section{Postoperative care}

The mare was put in a sling for four weeks. After six days the cast had to be removed with the patient standing because of partial-thickness skin sores at the dorsoproximal aspect of the metacarpus III. The cast was replaced by a Robert-Jones-Bandage. The mare showed no local or systemic signs of adverse drug reactions, and the operation wound healed uneventfully. After four weeks the horse was taken out of the sling and stall-rested in the clinic for another month. During the last week the Robert-Jones Bandage was replaced by a normal firm padded bandage. The mare was discharged and stallrested for another one-and-a-half months at home, followed by one month of hand-walking exercises. Exercise was increased progressively and after a total of four-and-a-half months the horse went into training to get broken in. Since the 23rd postoperative week the horse has been ridden every day at walk, trot and canter.

\section{Follow-up examinations}

Control radiographs were taken four and six weeks after surgery (Fig. 3 and 4). The mare was reevaluated at the clinic six and ten months after surgery. At six months an inconsistent lameness (grade 1 out of 5) was found, only sometimes being observable on circles, whereas ten months after surgery the horse showed no evidence of lameness under all circumstances. Neither signs of excessive proliferative bony reactions in comparison to the preoperative situation nor implant loosening could be observed radiographically (Fig. 5 and 6). The owner was very satisfied with the outcome by the mare reaching the intended use as a riding horse.

\section{Discussion}

Degenerative joint disease in young horses is uncommon, but has been reported earlier. Osteochondrosis as a cause for
DJD has been described in horses younger than three years of age (Trotter et al. 1982). Also selective weight bearing in horses younger than four years of age has been shown to be a cause of DJD developing in the contralateral support limb after severe lameness in the opposite limb (Ellis and Greenwood 1985). According to the case history, the latter patho-

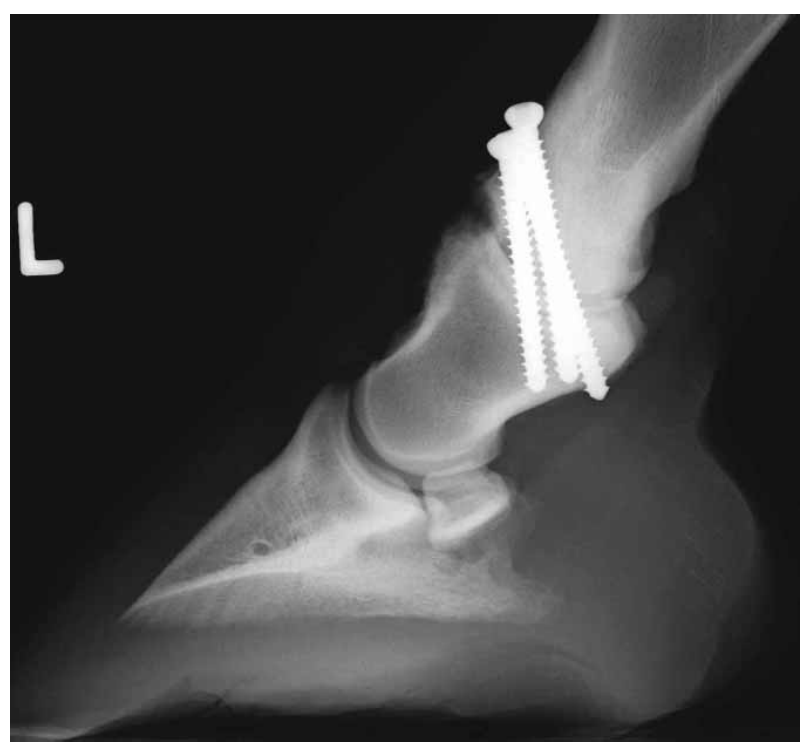

Fig 3 Radiograph taken four weeks after surgery: the defect of the dorsal aspect of the pastern joint can still be seen.

Röntgenbild 4 Wochen nach der Operation: Der Defekt im dorsalen Bereich des Krongelenks ist immer noch sichtbar.

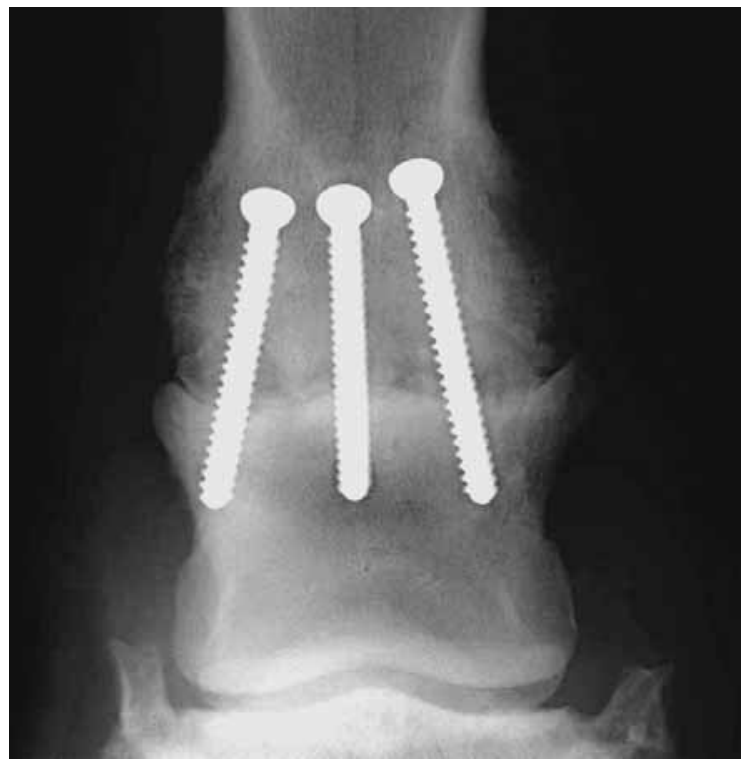

Fig 6 Radiograph taken six weeks after surgery: as a sign of bone fusion the central joint space is not clearly visible anymore. Röntgenbild 6 Wochen nach der Operation: Als Zeichen der Knochenfusion ist der zentrale Gelenkspalt nicht mehr klar erkennbar

genesis seems most probable in this mare. Arthrodesis using the parallel lag-screw fixation technique with two or three 5.5. $\mathrm{mm}$ screws extending across the joint in a dorsoproximal to palmaro-/plantarodistal direction is advocated for joints with osteoarthritis, subluxations, luxations or uniaxial eminence fractures of the middle phalanx (Watkins 1996, Aver 2000, MacLellan et al. 2001). Removal of all articular cartilage is considered important, since the remaining cartilage acts as a barrier to the bridging of the joint by osseous tissue (Watkins 1996). To gain access to the joint in order to remove any arti- 
cular cartilage, transection of the medial and lateral collateral ligaments of the pastern joint is necessary. It has been stated that the transection only minimally affects the stability of the arthrodesis (Watkins 1996). In contrast to that, Mcllwraith and Robertson (1998) recommend that these ligaments are preserved as much as possible because they contribute to the

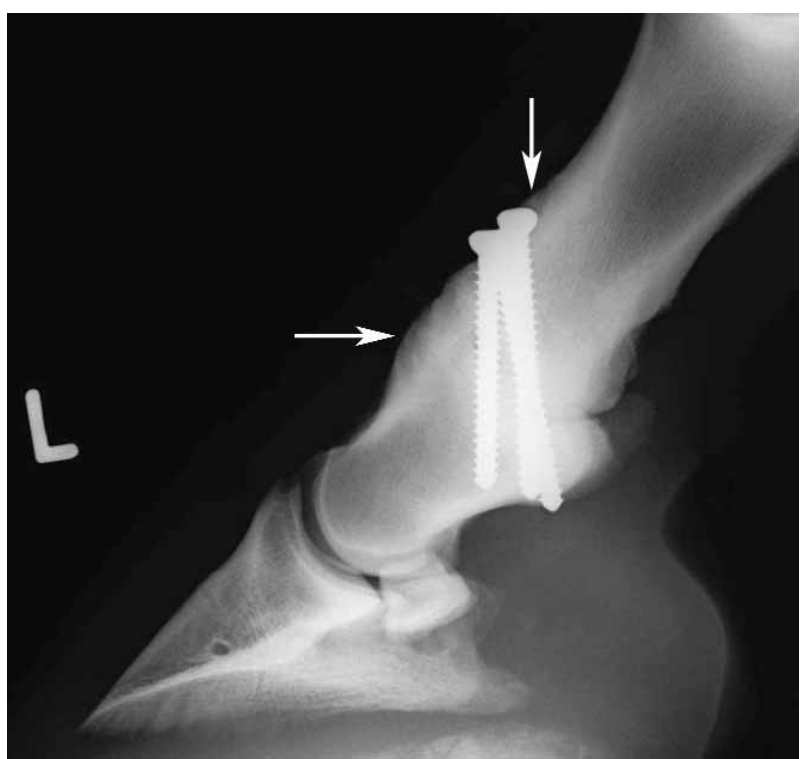

Fig 5 At ten months postoperatively a smooth bone surface at the dorsal aspect can be seen, as well as slight periosteal embedding of the screw heads (arrows).

Zehn Monate post operationem ist eine glatte Knochenoberfläche der dorsalen Kontur sowie eine leichtgradige periostale Einbettung der Schraubenköpfe sichtbar (Pfeile).

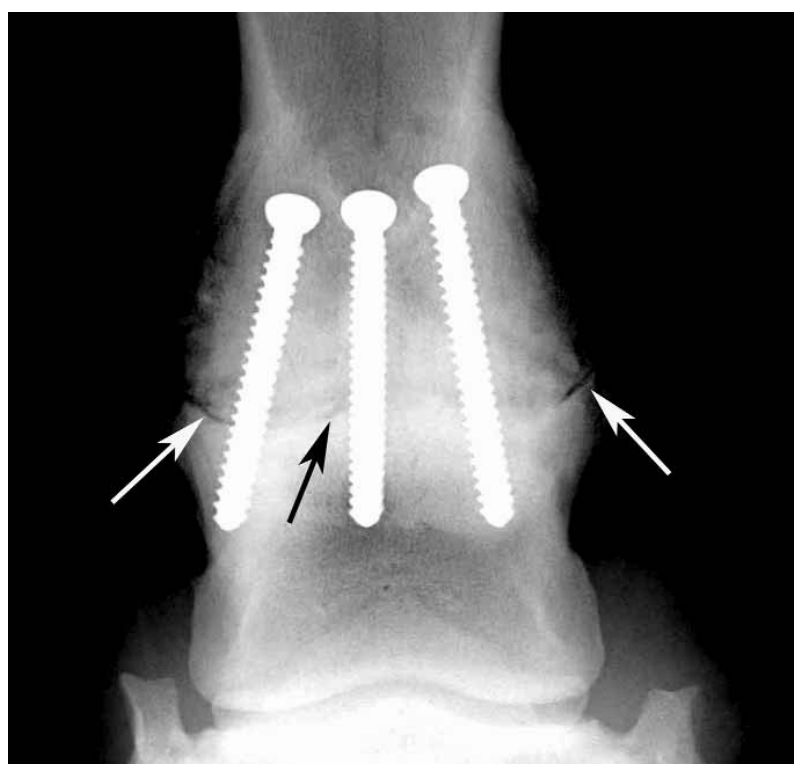

Fig 6 Radiograph ten months after surgery revealed advanced bony union - apart from a small area in the centre as well as at the medial and lateral joint margins (arrows) - with loss of subchondral bone definition.

Das Röntgenbild 10 Monate post operationem zeigt, mit Ausnahme eines schmalen Bereiches im Zentrum sowie an den lateralen und medialen Gelenksrändern (Pfeile), eine fortgeschrittene Knochenfusion, wobei die subchondrale Knochenplatte nicht mehr abgegrenzt werden kann.

stability of the joint. A higher initial stability of the arthrodesis may have been achieved in this case due to the preservation of collateral ligaments and periarticular proliferative bone formations. Furthermore, the possibility of getting an uneven bone-to-bone contact by not carefully removing the articular cartilage was prevented. Our hypothesis was that the osteoinductive abilities of nonglycosylated rhBMP-2 released from a fibrin matrix would outweigh the negative effects of leaving most of the articular cartilage in place.

It is known that a single application of rhBMP-2, one of the most potent factors available, without a carrier does not strongly influence the healing of bone defects due to its rapid clearance from the wound site (Balzer and Liebau 1999, Croteav et al. 1999). Therefore, a biodegradable matrix with a controlled release of the rhBMP-2 is necessary to achieve local bone formation induction in the gaps of the bone (Miyamoto et al. 1992, Sampath et al. 1992, Brekke and Toth 1998). Further important features of a carrier include the ability to be remodeled and replaced by the proteolytic activity associated with cells during migration and invasion as well as the ability to display a variety of adhesive ligands that directly bind to cell-surface receptors to provide adhesive and morphogenetic cues (Bruder and Fox 1999). Fibrin fulfills these features, being degraded by cell-derived proteases and providing binding sites through specific matrix-receptor mediated mechanisms (Pittman and Buettner 1989, Herbert et al. 1996). It is the natural wound healing matrix which allows cells to invade and interact in the wound site. It can be administered to the defect as a liquid precursor and the gelation forms a space-fitting hydrogel in the bone gaps. In vitro studies have shown that when mixed into fibrinogen, nglyrhBMP-2 mutants are retained in the matrix mimicking the natural fracture healing process with only small amounts of free BMP-2 in the wound area (Schmoekel et al. 2004a, 2004c). This composite has been successfully used to treat clinical cases of dogs and cats with bone defects, replacing a necessary cancellous bone autograft by the ngly-rhBMP2/fibrin composite (Schmoekel et al. 2004b).

In recent reports mean postoperative cast immobilisation averaged from four (Rick et al. 1986, MacLellan et al. 2001) to twelve-and-a-half weeks (Schaer et al. 2001) with a minimum of five days (MacLellan et al. 2001). A cast application for at least three (Stashak 2002) to six weeks (Watkins 1996, Mcllwraith and Robertson 1998, Nixon 1999) is recommended. In this case decubital ulcers occurred as a complication relating to the cast as described previously (Caron et al. 1990, MacLellan et al. 2001, Schaer et al. 2001), resulting in cast removal at the sixth postoperative day. Although the cast was removed so early, a successful outcome was reached, suggesting a sufficient stability of the internal fixation in combination with preservation of the collateral ligaments and surrounding proliferative tissues. Contrary to Schaer et al. (2001), where the parallel screw technique consistenly demonstrated a proliferative bony response, in this case follow-up radiographs did not reveal an excessive increase of proliferative bone formation, but rather a smoothing of the existing proliferative bone surfaces. Additionally no signs of implant loosening were seen.

It is unusual for the horse to become sound within one year after arthrodesis of the pastern joint and a one-year convalescent period after surgery is not unexpected (Mcllwraith and Robertson 1998). Return to full function required at least one to two years (forelimbs) and a half to one-and-a-half years (hindlimbs) (Martin et al. 1984). Mean time for horses being considered sound were twelve months (eight to twentyfour months)(Schaer et al. 2001). In the present case, however, the 
mare became sound within ten months after surgery. Prognosis for complete return or intended athletic function following arthrodesis of the pastern joint in the forelimb is said to be between 46 and 85 \% (Caron et al. 1990, MacLellan et al. 2001), which is significantly less than in the hindlimbs (Caron et al. 1990) due to the difference in normal weight bearing between fore- and hindlimbs (Martin et al. 1984). Steenhaut et al. (1985) described two cases of arthrodesis using lag screw technique in which the collateral ligaments had not been cut and no complete removal of articular cartilage was achieved, but which resulted in considerable periosteal proliferation and persistance of a visible joint space five months postoperatively. The successful outcome of this case with an early return to soundness cannot be completely explained by the modification of the surgical technique used. It can be assumed that the osteoinductive effects of nonglycosylated rhBMP-2 released from a fibrin matrix have strongly contributed to the enhanced bony fusion of the pastern joint, without having the disadvantage of reducing the bone-to-bone contact area as with autogenous bone grafts. Therefore, this ngly-rhBMP-2/fibrin composite is also of great potential interest for the promotion of joint fusion (e.g. in spavin) and fracture healing in combination with internal fixation in equines.

\section{Literature}

Aver J. A. (2000): Proximal interphalangeal arthrodesis: screw fixation. In: $\mathrm{AO}$ principles of equine osteosynthesis. Fackelman G.E., J. A. Auer, D.M. Nunamaker (eds.). Thieme, Stuttgart. p. 221-231

Balzer A. W. und C. H. Liebau (1999): Bone morphogenic proteinsBedeutung für die biologische Heilung. Z Orthop 137, 9-10

Brekke J. H. and J. M. Toth (1998): Principles of tissue engineering applied to programmable osteogenesis. J Biomed Mat Res 43, 365-73

Bruder S. P. and B. S. Fox (1999): Tissue engineering of bone. Clin Orthop 367, 86-93

Bukowiecki C. F. and L. R. Bramlage (1989): Treatment of a comminuted middle phalangeal fracture in a horse by use of a broad dynamic compression plate. J Am Vet Med Assoc 194, 1731-4

Caron J. P., P. B. Fretz, J. V. Bailey and S. M. Barber (1990): Proximal interphalangeal arthrodesis in the horse. A retrospective study and a modified screw technique. Vet Surg 19, 196-202

Colahan P. T., J. D. Wheat and D. M. Meagher (1981): Treatment of middle phalangeal fractures in the horse. J Am Vet Med Assoc $178,1182-5$

Crabill M. R., J. P. Watkins, R. K. Schneider and J. A. Auer (1995): Double-plate fixation of comminuted fractures of the second phalanx in horses: 10 cases (1985-1993). J Am Vet Med Assoc 207, 1458-61

Croteau S., F. Rauch, A. Silvestri and R. C. Hamdy (1999): Bone morphogenetic proteins in orthopedics: From basic science to clinical practice. Orthopedics 22, 686-95

Doran R. E., N. A. White // and D. Allen (1987): Use of a bone plate for treatment of middle phalangeal fractures in horses: Seven cases (1979-1984). J Am Vet Med Assoc 191, 575-8

Ellis D. R. and R. E. Greenwood (1985): Six cases of degenerative joint disease of the proximal interphalangeal joint of young Thoroughbreds. Equine Vet J 17, 66-8

Groom L. J., E. M. Gaughan, J. D. Lillich and L. W. Valentino (2000): Arthrodesis of the proximal interphalangeal joint affected with septic arthritis in 8 horses. Can Vet J 41, 117-23

Herbert C. B., G. D. Bittner and J. A. Hubbell (1996): Effects of fibrinolysis on neurite growth from dorsal root ganglia cultured in twoand three-dimensional fibrin gels. J Compar Neuro 365, 380-91

Kirker-Head C. A. (1995): Recombinant bone morphogenetic proteins: Novel substances for enhancing bone healing. Vet Surg 24, 408-19
MacLellan K. N. M., W. H. Crawford and D. G. MacDonald (2001): Proximal interphalangeal joint arthrodesis in 34 horses using two parallel $5.5 \mathrm{~mm}$ cortical bone screws. Vet Surg 30, 454-9

Martin G. S., C. W. Mcllwraith, A. S. Turner, A. J. Nixon and T. S. Stashak (1984): Long-term results and complications of proximal interphalangeal arthrodesis in horses. J Am Vet Med Assoc 184, 1136 40

Mcllwraith C. W. and J. T. Robertson (1998): Arthrodesis of the proximal interphalangeal joint. In: Mcllwraith \& Turner's equine surgery: Advanced techniques. 2nd edn. Mcllwraith C.W. and J.T. Robertson (eds.). Williams \& Wilkins, Baltimore, p. 187-92

Miyamoto S., K. Takaoka and J. Hashimoto (1992): A new synthetic biodegradable polymer suitable as a carrier for bone morphogenetic protein. Trans 38th Ann Orthop Res Soc 1992, p. 70

Nixon A. J. (1999): The phalanges and metacarpometatarsophalangeal joint. In: Equine surgery. 2nd edn. Auer J.A. and J.A. Stick (eds.). W.B. Saunders, Philadelphia, p. 792-809

Pittman R. N. and H. M. Buettner (1989): Degradation of extracellular matrix by neuronal proteases. Dev Neuro 11, 361-75

Rick M. C., D. Herthel and C. Boles (1986): Surgical management of middle phalangeal fractures and high ringbone in the horse: $A$ review of 16 cases. Proc. 32nd Ann. Meeting Am Assoc Equine Pract, Lexington, KY, USA, p. 315-21

Sampath T. K., E. Ozkaynak and M. W. Wolfe (1992): Recombinant human osteognetic protein (hOP-1) induces new bone formation with a specific activity comparable to that of natural bone $O P$. Trans 38th Ann Orthop Res Soc, p. 72

Schaer T. P., L. R. Bramlage, R. M. Embertson and S. Hance (2001): Proximal interphalangeal arthrodesis in 22 horses. Equine Vet $J$ 33, 360-5

Schmoekel H. G., J. C. Schense, F. E. Weber, K. W. Graetz, D. Gnaegi, R. Mueller and J. A. Hubbell (2004a): Bone healing in the rat and dog with nonglycosylated BMP-2 demonstrating low solubility in fibrin matrices. J Orthop Res, 22 (2), 376-81

Schmoekel H. G., F. E. Weber, B. von Rechenberg, J. C. Schense, P. Schawalder and J. A. Hubbell (2004b): Treatment of nonunions with nonglycosylated recombinant human bone morphogenetic protein-2 delivered from a fibrin matrix. Vet Surg 33, 112-8

Schmoekel H. G., F. E. Weber, U. Rytz, J. C. Schense, K. W. Graetz, P. Schawalder and J. A. Hubbel (2004c): Bone repair with a form of BMP-2 engineered for incorporation into fibrin cell ingrowth matrices. Biotechnol Bioeng, in press

Schneider J. E., B. L. Carnine and M. M. Guffy (1978): Arthrodesis of the proximal interphalangeal joint in the horse: A surgical treatment for high ringbone. J Am Vet Med Assoc 173, 1364-9

Stashak T. S. (2002): Degenerative joint disease of the proximal interphalangeal (pastern) joint (high ringbone). In: Adams' lameness in horses. 5th edn. Stashak T.S (ed.). Lippincott Williams \& Wilkins, Philadelphia 2002, p. 733-41

Steenhaut M., F. Verschooten and A. De Moor (1985): Arthrodesis of the pastern joint in the horse. Equine Vet J 17, 35-40

Trotter G. W., C. W. Mcllwraith, R. W. Norrdin and A. S. Turner (1982): Degenerative joint disease with osteochondrosis of the proximal interphalangeal joint in young horses. J Am Vet Med Assoc 180,1312-8

Watkins J. P. (1996): Fractures of the middle phalanx. In: Equine fracture repair. Nixon AJ (ed.). W.B. Saunders, Philadelphia 1996, p. 129-45

Weber F. E., G. Eyrich, K. W. Graetz, F. E. Maly and H. F. Sailer (2002): Slow and continuous application of human recombinant bone morphogenetic protein via biodegradable poly(lactide-coglycolide) foamspheres.

Dr. Britta Lippold

Dept. of Clinical Veterinary Medicine, Equine Clinic

University of Berne

Laengassstrasse 124

3012 Berne, Switzerland

britta.lippold@knp.unibe.ch 